\title{
Composition of the Neoarchean granitic rocks from the Bienville and La Grande domains, Superior Province, Canada
}

\author{
LUKÁŠ ACKERMAN ${ }^{1}$, JIŘí ŽÁK ${ }^{2}$, MARTIN SVOJTKA ${ }^{1}$,
} FILIP TOMEK ${ }^{1,2}$, JIŘÍ SLÁMA ${ }^{2}$

${ }^{1}$ Institute of Geology of the Czech Academy of Sciences, Prague, Czech Republic; ackerman@gli.cas.cz

${ }^{2}$ Faculty of Science, Charles University, Prague, Czech Republic

The Bienville and La Grande domains are Meso- to Neoarchean lithotectonic units of the north-eastern Superior Province [1]. The Bienville domain belongs to the Hudson Bay Terrane and it is predominantly composed of granitic (tonalite-trondhjemite-granite; TTG) and gneissic rocks with an age of $\sim 2.7 \mathrm{Ga}$. By contrast, the La Grande domain is tradionally divided into the $\sim 2.7$ Ga southern part (Eastmain) with a high proportion of volcano-sedimentary rocks and the 3.4-2.7 Ga old northern part (La Grande) with similar characteristics as Bienville $[1,2]$.

Here, we present new U-Pb LA-ICP-MS zircon ages, major/trace element geochemistry and $\mathrm{Sm}-\mathrm{Nd}$ isotopic compositions for the granitic/gneissic rocks (TTG, granite) from the (1) southernmost part of the Bienville domain and (2) a N-S transect through both parts of the La Grande domain. New $\mathrm{U}-\mathrm{Pb}$ ages $(2210 \mathrm{Ma})$ for the granitic rocks from the Eastmain part are indistinguishable within the given error from those determined in the Bienville domain $(\sim 2700$ $2720 \mathrm{Ma}$ ). The sampled Bienville rocks exhibit wide range in composition from monzogabbro to granite with variable LREE-enrichment $\left(\mathrm{La}_{\mathrm{N}} / \mathrm{Yb}_{\mathrm{N}}=20-57\right)$, but very narrow range of $\varepsilon_{\mathrm{Nd}(\mathrm{i})}(+0.3$ to +0.6$)$ and $\mathrm{T}_{\mathrm{DM}}$ model ages $(2.79-2.82 \mathrm{Ga})$ indicating derivation from homogeneous, mildly evolved source. These signatures are different from those reported from the northern parts of the Bienville domain [2]. By contrast, the La Grande domain is characterized by rocks with tonalitic (low-K) composition dominating in the northern part accompanied by granodiorite-granite common in the Eastmain part. Collectively, rocks from both parts of the La Grande domain yield overlapping, highly variable $\mathrm{La}_{\mathrm{N}} / \mathrm{Yb}_{\mathrm{N}}$ (3-74) paralleled by wide range of $\varepsilon_{\mathrm{Nd}(\mathrm{i})}(-0.9$ to +2.1$)$ and $\mathrm{T}_{\mathrm{DM}}$ model ages (2.07-3.74 Ga) suggesting derivation mostly from juvenile sources.

Funded by the Czech Science Foundation project 19-08066S.

[1] Percival et al. (2012) Geol Assoc Canada Spec Pap 49, 321-378. [2] Boily et al. (2009) Prec Res 168, 23-44. 